\title{
Zarf Kavramının Öğretiminde Örnek Ayrıntılama Stratejisinin Kavram Öğrenmeye, Kalıcılığa ve Transfere Etkisi*
}

\section{The Effect of Example Elaboration Strategy on Concept Learning, Retention and Transfer on Teaching Adverb Concept}

\author{
Dilber NERGİZ **, Mükerrem AKBULUT TAŞ ***
}

\begin{abstract}
Öz: Örnekler, kavramın daha somut ve anlaşı1ır hale gelmesini kolaylaştırdığı için kavramların öğrenilmesini olumlu yönde etkilemektedir. Bu çalışmada, Türkçe dersinde zarf kavramının öğretiminde örnek ayrıntılama stratejisinin kavram öğrenme başarısına, kalıcıllğa ve transfere etkisi araştırılmıştır. Öntest-sontest kontrol gruplu deneysel modele göre desenlenen bu çalışma, ortaokul yedinci sinıf öğrencileri ile gerçekleştirilmiştir. Çalışma grubu, deney grubunda 30, kontrol grubunda 30 öğrenci olmak üzere 60 öğrenciden oluşmaktadır. Veriler, okuduğunu anlama testi (OAT), kavram öğrenme testi (KÖT) ve transfer testi kullanılarak elde edilmiştir. Verilerin analizinde aritmetik ortalama, standart sapma, bağımsız gruplar $t$ testi ve kovaryans analizi (ANCOVA) kullanılmıştır. Araştırma sonucunda deney ve kontrol grubundaki öğrencilerin okuduğunu anlama ve kavram öğrenme öntest toplam başarı puanları kontrol edildiğinde, kavram öğrenme sontest düzeltilmiş ortalamaları arasında deney grubu lehine anlamlı bir farklılık saptanmıştır. Kalıcilık testi ve transfer testi düzeltilmiş ortalamaları açısından deney ve kontrol grupları arasında anlamlı bir farklılık belirlenmemiştir. Araştırmada ulaşılan bulgulara göre örnek ayrıntılama stratejisinin kavram öğrenmede kısmen etkili bir strateji olduğu belirtilebilir.
\end{abstract}

Anahtar Kelimeler: Kavram öğretimi, örnek ayrıntılama stratejisi, zarf kavramı, ortaokul öğrencileri.

\begin{abstract}
Since the examples facilitate the concept to become more concrete and understandable, they positively affect the learning of concepts. In this study, the effect of example elaboration strategy on the concept learning success, retention and transfer in the teaching adverb concept in Turkish lesson was examined. This study, designed as the experimental research model with a pre-test/post-test control group, was carried out with 7th grade students who studied in middle school. The study group consists of 60 students (the experimental group: 30 students, the control group: 30 students). Data were obtained by using reading comprehension test (OAT), concept learning test (CLT) and transfer test. In data analysis, mean, standard deviation, independent groups $t$ test and covariance (ANCOVA) analysis were used. As a result, when the pre-test scores of the students in the experimental and control groups were checked, a significant difference was found in favor of the experiment group between the corrected mean of the concept learning posttest scores. No significant difference was found between experiment and control groups in terms of retention test and transfer test corrected mean. According to the results obtained, it can be stated that the example elaboration strategy is partially effective in concept learning.
\end{abstract}

Keywords: Concept teaching, example elaboration strategy, adverb concept, secondary school students.

\section{Giriș}

Kavramsal anlayışın oluşmasında örnekler önemli bir yer tutmaktadır. Sınıflarda öğrencilere bir kavram hakkındaki bilgileri sorulduğunda çoğu zaman kavramın örneklerinin kavramın tanımından daha hızlı hatıllandığına ve ifade edildiğine tanık oluruz. Kavramın örnek ve örnek olmayanları, kavramın tanımının ve özelliklerinin daha somut ve anlaşılır olmasını sağladığı için kavramların öğrenilmesini olumlu yönde etkilemektedir (Karataş Coşkun, 2011). Örnekler, kavramın ayırt edici özelliklerinin (ortak özellikler) tamamına sahip olan olaylar, durumlar,

\footnotetext{
*Bu çalışma, Çukurova Üniversitesi Sosyal Bilimleri Enstitüsünde Eylül 2019 tarihinde tamamlanan ve birinci yazarın ikinci yazar danışmanlığında gerçekleştirdiği yüksek lisans tezinden üretilmiş olup "VI ${ }^{\text {th }}$ International Eurasian Educational Research Congress"de (Ankara, 2019) sözlü bildiri olarak sunulmuştur.

**Sorumlu yazar, Türkçe Öğretmeni, Küçükkadı Ortaokulu, Diyarbakır-Türkiye, ORCID: 0000-0001-7210-2784, e-posta: sezgindilber89@gmail.com

***Dr. Öğr. Üyesi, Çukurova Üniversitesi, Eğitim Fakültesi, Adana-Türkiye, ORCID: 0000-0002-8398-9357, e-posta:mtas@cu.edu.tr
} 
nesneler veya sembollerdir (Martorella, 1986; Merrill, Tennyson ve Posey, 1992). Örnek olmayanlar ise bir kavramın ayırt edici özelliklerinin tamamına sahip olmayan ve o kavram sınıfı içerisinde yer almayan olaylar, durumlar, nesneler veya sembollerdir (Martorella, 1986; Merrill vd., 1992). Bir kavramın öğretiminde öğrencilerin genelleme ve ayırt etme becerilerini edinmesi, aşırı ve dar genelleme hatalarının önlenmesi amacıyla o kavramın örnek ve örnek olmayanları eşleştirilerek mantıksal bir set halinde öğrencilere sunulmalıdır (Klausmeier, 1990; Tennyson ve Park, 1980). Bununla birlikte kavramların öğretiminde hangi yolun en etkili olduğunu söylemek her durum için her zaman mümkün olmayabilir. Hannon'un (2012) da belirtiği gibi ögrencilerin bir bilgiyi öğrenmesinde, bellekte kalıcı bir şekilde saklamasında en etkili yolun ne olduğunun tek ve basit bir yanıtı yoktur. Ancak daha iyi olabilecek bir yolun olup olmadığı test edilebilir. Alan yazında örnek ayrıntılama, kavram öğrenmede daha etkili ve verimli bir sonuç alabilmek için üzerinde çalışılan stratejilerden birisidir (Charney ve Reder, 1986; Hamilton, 2004; Hannon, 2012; Hannon, Lozano, Farias, Hernandez ve Fuhrman, 2010; Mayer, 1980; Park, 1984).

Ayrıntılama, yeni bilgi ile ilişkili ya da hatırlanması istenen bilgi arasındaki bağı açıklığa kavuşturan her türlü güçlendirmedir (Charney ve Reder, 1986; Hamilton, 2004). Bu güçlendirme, bilgiyi bellekte yeniden yapılandırmak ve zenginleştirmek için kullanılabilir. Ayrıntılama, aynı zamanda öğrencinin önceki bilgilerini, şemalarını aktif hale getirerek yeni bilgiyle ilişkilendirmesini, yeni bilgiyi genişletmesini ve derinleştirmesini sağlayan üretici bir stratejidir (Fiorella ve Mayer, 2016). Bu yönüyle ayrıntılama, öğrencilerin yeni bilgiyi, derinliğine ve anlamlı bir şekilde uzun süreli belleğe kodlamasına ve daha kolay hatırlayabilmesine yardım edebilir (Lewalter, 2003; Schunk, 2014). Bunun yanında ayrıntılama sadece önceki bilgi ile yeni bilgiyi ilişkilendirmeyi ve bellekte düzenlemeyi sağlamamakta, aynı zamanda örtük ya da açık bir şekilde benzerlikleri ve farklılıkları da işlemeyi gerektirmektedir (Dunlosky, Rawson, Marsh, Nathan ve Willingham, 2013). Benzerlikleri ve farklılıkları belirleme, kavram öğretiminde ayırt etme ve genelleme becerilerinin edinimi açısından da gereklidir.

Kavram öğretiminde ayrıntılama daha çok "örnek ayrıntılama" olarak karşımıza çıkmaktadır. Örnek ayrıntılama, sunulan örnekler üzerinde ayırt edici özellikleri gösterme, kavramın tanımı ve özellikleri açısından (çözülmüş örnek kullanarak) örneğin neden örnek olup olmadığını açıklama, örnek ve örnek olmayanları karşılaştırma, kavramın tanımlarını benzerlik ve farklılık yönünden karşılaştırma ya da kavrama bir örnek verme gibi farklı biçimlerde uygulanmaktadır (Hamilton, 2004; Hannon, 2012; Hannon vd., 2010). Örneğin Park (1984), örnek karş1laştırma stratejisi ile ayırt edici özellikleri belirleme stratejisinin etkisini incelediği çalışmada ayırt edici özellik belirleme stratejisinin, öğretim sırasında sunulan yeni örnekleri sınıflamada daha etkili olduğunu, buna karşlık sontest ve kalıcılık testinde örnek karşılaştırma stratejisi ile öğrenen grubun daha başarılı olduğunu belirlemiştir. Hamilton (2004), kavramın içerik ögeleri ile ilgili düzenlemenin yapıldığ 1 ve ilişkisel ayrıntılamanın (iki kavram arasındaki benzerlikleri ve farklılıkları bulma) eklendiği metnin, bu ayrıntılamanın eklenmediği ve içerik düzenlemesinin yapılmadığı metne göre kavram öğrenmeyi anlamlı bir şekilde etkilediğini saptamıştır. Hannon (2012) ise türdeş olan ve türdeş olmayan iki kavramın öğretiminde, tanımı ve özellikleri ögrenmede tanımları karşılaştırmanın, örnek ayrıntılamadan daha etkili olduğu sonucuna ulaşmıştır. Alan yazında, öğrenci örneklerinin, örneklerin ve örnek olmayanların farklı biçimlerde sunumunun, örneklerle birlikte dönütün kavram öğrenmeye etkisi incelenmiştir (Bolkan ve Goodboy, 2019; Finn, Thomas ve Rawson, 2018; Griffin, 1993; Rawson ve Dunlosky, 2016; Rawson, Thomas ve Jacoby, 2015; Watson ve Shipman, 2008; Zamary ve Rawson, 2018a; 2018b). Örneklerin, öğrenme-öğretme sürecindeki rolü ve örnek ayrıntılamanın etkisi çözülmüş örneklerle (worked-examples) daha çok önem kazanmıştır (Catrambone ve Yuasa, 2006; Foster, Rawson ve Dunlosky, 2018; Özcan, Kılıç ve Obalar, 2018; Roelle, Hiller, Berthold ve Rumann, 2017). Corral ve Carpenter (2020) da doğru ve yanlış örneklerin ve dönüt türünün karmaşık kavramları öğrenmeye etkisini incelemişlerdir. Araştırma sonucunda doğru ve 
yanlış örneklerin birlikte sunulduğu ve açıklayıcı dönütün verildiği grubun sınıflama ve transfer testinde daha yüksek performans gösterdiği belirlenmiştir. Alan yazında da belirtildiği gibi örnekler, öğrencilerin kavramlarla ilgili kavrayışlarını anlamamızı sağlayan ve belirli bir bağlamda kavramın nasıl kullanıldığını görmemizi sağlayan kavram öğesidir (Zaslavsky, 2014). $\mathrm{Bu}$ yönüyle örnekler kavram öğrenme ve kavram öğretiminde, öğrencinin kavramsal bilgiyi nasıl inşa ettiğini gösteren etkili bir kavramsal araçtır.

Türkiye' de kavram öğrenme ve öğretimi ile ilgili çalışmaların fen bilimleri, matematik ve sosyal bilgiler alanında yoğunlaştığı, bu alanlarda farklı etkinliklerin yöntem ve stratejilerin kavram öğrenmeye etkisinin incelendiği gözlenmiştir (Baştürk Şahin, Şahin ve Tapan Broutin, 2017; Beydoğan ve Hayran, 2015; Bolat ve Dolapçıŏlu, 2020; Çakar, 2013; Çavumirza, 2018; Hacıŏlu, 2011; İncikabı ve Kılıç, 2013; Kırılmazkaya, 2014; Pınar ve Akdağ, 2012; Talaslıoğlu, 2016; Uc, 2019; Uysal, 2016; Yenilmez ve Demirhan, 2013; Yıldız, 2013). Buna karşıllk Türkçe dersinde farklı etkinliklerin, modellerin ve stratejilerin kavram oluşturmaya ya da kavram öğrenmeye etkisini ortaya koyan çalışmalar yapılmıştır (Bayram, 2015; Bilgin, 2018; Cevher, 2019; Koçmar, 2017; Kurt, 2018; Polatcan, 2013; Sayın, 2014; Sügümlü, 2009; Temizyürek ve Türktan, 2015). Dolayısıyla Türkiye'de kavram öğrenme ve öğretimi üzerinde sıklıkla çalışıldığ 1 , buna karş11ık kavram öğretiminde örneklerin rolünü ve önemi ortaya koyan çalışmaların az olduğu belirtilebilir (Akbulut Taş ve Karataş Coşkun, 2012; Alkan ve Güven, 2018; Sağlam Kaya, 2019).

Öğretim programlarının içeriğinin önemli bir ögesi olan kavramların, okullarda kasıtlı bir şekilde kazandırılması amaçlanmaktadır. Dahası kavram öğrenme, öğrencinin öğrenme-öğretme süreci sonunda edinmesi gereken bir zihinsel beceridir ve ilke öğrenme, problem çözme gibi üst düzey becerilerin edinilmesinin temelidir (Gagne, Wager, Golas ve Keller, 2005). Kavramlar, diğer derslerde olduğu gibi Türkçe dersi içeriğinde de önemli bir yer tutmaktadır. Türkçe Öğretim Programı'nda (Milli Eğitim Bakanlığı [MEB], 2018) öğrencilerde dinleme, okuma, yazma ve konuşma gibi dört temel dil becerisinin gelişimi amaçlanmaktadır. $\mathrm{Bu}$ amaçla gerçekleştirilen dil bilgisi öğretimi öğrencilerin dili, dil bilgisi kurallarına göre öğrenmesini ve bilinçli bir şekilde kullanabilmesini desteklemektedir (Yaman, 2006). Dahası, Türkçe Öğretim Programı'nda (MEB, 2018) üst düzey zihinsel becerilerin de geliştirilmesi amaçlanmaktadır. Böyle üst düzey zihinsel beceriler, etkili bir şekilde gerçekleştirilen kavram edinimiyle mümkün olabilir. $\mathrm{Bu}$ sebeple dil bilgisi öğretiminde anlaşılması, öğrenilmesi zor olan kavramların öğrenciler tarafından doğru bir şekilde anlamlandırılabilmesi için farklı öğretim stratejilerinin kullanılmasına gereksinim duyulabilir. Türkiye'de kavram öğretimi çalışmalarında örnek ayrıntılama stratejisinin etkisini inceleyen bir çalışmaya ulaşılamamıştır. Ayrıca Türkçe dersiyle ilgili çalışmalarda daha çok sıfat kavramıyla çalışıldığı (Bayram, 2015; Çocuk, 2012; Polatcan, 2013; Süğümlü, 2009) belirlenmiştir. Zarf kavramının öğretimine yönelik çalışmaların daha az olduğu ifade edilebilir (Cevher, 2019; Tan, 2008). Dolayısıyla örnek ayrıntılama stratejisinin, yedinci sınıf dil bilgisi konularından olan "zarf” kavramının öğretimindeki etkisinin incelendiği böyle bir çalışmanın dil bilgisi ile ilgili temel kavramların öğretimi için yararlı olabileceği düşünülmektedir.

Türkçe dersinde geliştirilmesi amaçlanan dört temel dil becerilerinden birisi okumadır. Okuma, “...yazar ve okuyucu arasında etkili iletişime dayalı, uygun bir yöntem ve amaç doğrultusunda düzenli bir ortamda gerçekleştirilen anlam kurma sürecidir" (Akyol, 2005, s. 15). Okuduğunu anlama ise yazılı ve anlamlı sözcük, kavram, cümle, paragraf veya metinleri algılama ve belirli işlemlerden geçirerek yeniden anlamlandırma işlemidir (Şengül ve Yalçın, 2004). Özellikle yazılı bir metinden kavram öğrenmede öğrencinin okuduğunu anlaması, soyutlama, genelleme ve ayırt etme becerilerini doğru bir şekilde gerçekleştirmesini sağlayabilir. Dolayısıyla bu çalışmadaki öğrenciler çalışma kitapçıklarını kullanarak deneysel süreçteki işlemleri gerçekleştireceklerinden ve bu görevler okuduğunu anlamaya dayandığından okuduğunu anlama becerisi, kontrol edilen bir değişken olarak ele alınmıştır. Bu çalışmanın temel amacı, örnek 
ayrıntılama stratejisinin kavram öğrenme başarısına, kalıcılığa ve transfere etkisini belirlemektir. Bu kapsamda aşağıdaki sorulara yanıt aranmıştır:

1. Deney ve kontrol grubunun kavram öğrenme öntest ve okuduğunu anlama öntest toplam puanları kontrol edildiğinde, kavram öğrenme sontest düzeltilmiş puanları örnek ayrıntılama stratejisinin uygulandığı deney grubu lehine anlamlı bir farklılık göstermekte midir?

2. Deney ve kontrol grubunun kavram öğrenme sontest toplam puanları kontrol edildiğinde,

2a. Kalıcılık testi düzeltilmiş puanları örnek ayrıntılama stratejisinin uygulandığ1 deney grubu lehine anlamlı bir farkl1l1k göstermekte midir?

2b. Transfer testi düzeltilmiş puanları örnek ayrıntılama stratejisinin uygulandığ deney grubu lehine anlamlı farklılık göstermekte midir?

\section{Yöntem}

Bu bölümde araştırma modeli, çalışma grubu, veri toplama araçları, öğretim materyallerinin geliştirilmesi, deneysel işlem, verilerin analizinde kullanılan teknikler ve müdahalede uygulanan etik kurallara ilişkin açıklamalara yer verilmiştir.

\section{Araștırma modeli}

$\mathrm{Bu}$ araştırma, öntest-sontest kontrol gruplu deneysel bir çalışmadır. Gerçek deneysel desenlerde katılımcılar deneysel koşullara yansız bir şekilde atanmaktadır (Büyüköztürk, 2001). Bu çalışmada katılımcılar deneysel koşullara yansız bir şekilde atanabildiği için öntest-sontest kontrol gruplu deneysel desen kullanılmıştır. Çalışmada deney ve kontrol gruplarına yansız atama yapabilmek amacıyla katılımcıların isimleri kağıtlara yazılarak bir torbada toplanmıştır. Sonrasında araştırmacılar ve bir gözetmen eşliğinde kura yöntemiyle isimler çekilerek sirasıyla deney ve kontrol grubuna yazılmıştır. Böylelikle deney ve kontrol grupları oluşturulmuştur. $\mathrm{Bu}$ çalışmanın bağımsız değişkeni öğretim yöntemidir (örnek ayrıntılama stratejisi ile mevcut programa dayalı ve örnek ayrıntılama stratejisinin uygulanmadığı yöntem). Araştırmanın bağımlı değişkenleri ise kavram öğrenme başarısı, kalıcılık ve transferdir. Araştırmada kontrol edilen değişkenler dışında okul içinde ve dışında kontrol edilemeyen değişkenlerin, deney ve kontrol grubundaki öğrencileri benzer düzeyde etkilediği varsayılmıştır. Araştırma modeli Tablo 1 'de verilmiştir.

Tablo 1

Araştırma Modelinin Simgesel Görünümü

\begin{tabular}{lccccc}
\hline Gruplar & Öntestler & Deneysel işlem & Sontest & Transfer testi & Kalıcılık testi \\
\hline $\mathrm{G}_{1}$ & $\mathrm{O} 1.1+\mathrm{O} 2.1$ & $\mathrm{X}_{1}$ & $\mathrm{O} 1.2$ & $\mathrm{O} 3.1$ & $\mathrm{O} 1.3$ \\
$\mathrm{G}_{2}$ & $\mathrm{O} 4.1+\mathrm{O} 5.1$ & $\mathrm{X}_{2}$ & $\mathrm{O} 4.2$ & $\mathrm{O} 6.1$ & $\mathrm{O} 4.3$ \\
\hline
\end{tabular}

Not. G1: Örnek ayrıntılama stratejisinin kullanıldığı deney grubu, G2: Örnek ayrıntılama stratejisinin uygulanmadığı mevcut programa dayalı öğretim yapılan kontrol grubu, X1: Örnek ayrıntılama stratejisinin kullanıldığı deneysel işlem, X2: Örnek ayrıntılama stratejisinin uygulanmadığı mevcut programa dayalı öğretim. O1.1-O4.1: KÖT öntesti. O2.1-O5.1: OAT öntesti. O1.2-O4.2: KÖT sontesti. O3.1-O6.1: Transfer testi. O1.3-O4.3: Kalıc1lık testi.

\section{Çalışma grubu}

Bu araştırma, 2018-2019 eğitim öğretim yılında Adana ilinde, birinci araştırmacının yedi yıldır Türkçe öğretmeni olarak görev yaptığı ve tam gün eğitim veren bir devlet okulunda gerçekleştirilmiştir. Okuldaki öğrencilerin çoğunluğu, göçle gelen, düşük gelirli ve kardeş sayısı fazla olan ailelerin çocuklarıdır. Erkek öğrenciler, ailenin ekonomisine katkıda bulunmak amacıyla okul saatleri dışında bir işte çalışmaktadır. Sosyo-kültürel yapısının kısaca tanıtıldığı böyle bir okulda öğrenim gören dokuz yedinci sınıf şubesinden birinci yazarın Türkçe derslerine girdiği iki yedinci sınıf şubesi ve 69 yedinci sınıf öğrencisi (Deney grubu: 35; kontrol grubu 34 öğrenci) çalışma grubunda yer almıştır. Araştırmanın birinci yazarı tam gün çalıştığından deney 
ve kontrol grupları aynı okuldan seçilmiştir. Bu çalışmada deneysel işlemde kullanılan yazılı metinler okuma-yazma etkinliklerini içermektedir. Dolayısıyla deney grubundaki iki öğrenci, kontrol grubunda ise bir öğrenci okuma- yazma sorunu yaşadığından bu öğrenciler deneysel işleme katılmıştır, ancak testlerden aldıkları puanlar analiz edilmemiştir. Yine deneysel işlemin tamamına katılamayan, öntest veya sontestleri, kalıcılık veya transfer testini alamayan, bu testleri yönergeye uygun dolduramayan her iki gruptan üçer öğrenci verilerin analizi aşamasında çalışma grubundan çıkartılmıştır. Böylece araştırma bulguları, deney grubunda 30, kontrol grubunda 30 öğrenciden elde edilen verilerle sınırlandırılmıştır. Bu çalışmadaki deney grubundaki öğrencilerin \%56,7'si (17) k1z, \%43,3'ü (13) erkektir. Kontrol grubundaki öğrencilerin ise \%46,7'si (14) k1z, \%53,3'ü (16) erkektir. Deney ve kontrol grubundaki öğrencilerin cinsiyet açısından benzerlik gösterip göstermediğini belirlemek amacıyla yapılan ki-kare analizi sonucunda $\left(\chi_{(1)}^{2}=0,601\right.$ p $\left.>0,05\right)$ her iki grubun da benzerlik gösterdiği belirlenmiştir.

Araştırmada deney ve kontrol grubundaki öğrencilerin Türkçe dersi ortalama akademik başarı notları, okuduğunu anlama becerisi ve zarf kavramı ile ilgili bilgileri açısından denk olup olmadıkları deneysel işlem öncesi test edilmiştir. Türkçe dersi ortalama akademik başarı notları, öğrencilerin beşinci ve altıncı sınıf Türkçe dersi yılsonu ortalamalarının tekrar ortalaması alınarak elde edilmiştir. Deney ve kontrol grupları arasında, Türkçe dersi ortalama akademik başarı notları, OAT öntest puanları ve KÖT öntest puanları açısından anlamlı bir fark olup olmadığı bağımsız gruplar $t$ testiyle incelenmiştir ve elde edilen sonuçlar Tablo 2'de verilmiştir.

Tablo 2

Deney ve Kontrol Gruplarının Türkçe Dersi Ortalama Akademik Başarı Notları, OAT ve KÖT Öntest Puanlarına İlişkin Aritmetik Ortalama, Standart Sapma ve Bağımsız Gruplar $t$ Testi Sonuçları

\begin{tabular}{lllccccc}
\hline Değişkenler & Gruplar & $\mathrm{N}$ & $\overline{\mathrm{X}}$ & $\mathrm{SS}$ & $\mathrm{Sd}$ & $t$ & $\mathrm{p}$ \\
\hline $\begin{array}{l}\text { Türkçe dersi ortalama } \\
\text { akademik başarı notu }\end{array}$ & Deney & 30 & 70,05 & 17,89 & 58 & 0,222 & 0,825 \\
\hline KAT öntest puanları & Kontrol & 30 & 69,09 & 15,62 & & & \\
& Koney & 30 & 18,00 & 3,91 & \multirow{2}{*}{58} & 0,985 & 0,329 \\
\hline KÖT öntest puanları & 30 & 16,90 & 4,70 & & & \\
& Deney & 30 & 12,63 & 5,04 & \multirow{2}{*}{58} & \multirow{2}{*}{$-0,080$} & 0,936 \\
& Kontrol & 30 & 12,73 & 4,59 & & & \\
\hline
\end{tabular}

Tablo 2'ye göre deney ve kontrol grubundaki öğrencilerin Türkçe dersi ortalama akademik başarı not ortalamaları $(t(58)=0,222, \mathrm{p}>0,05)$; OAT öntest puanlarının ortalamaları $(t(58)=$ $0,985, \mathrm{p}>0,05)$ ve KÖT öntest puanlarının ortalamaları $(t(58)=0,080, \mathrm{p}>0,05)$ arasında anlaml bir farklılık olmadığı, grupların birbirine denk yapıda olduğu belirtilebilir.

\section{Veri toplama araçları}

Araştırma verilerini elde etmek amacıyla kullanılan OAT, KÖT ve transfer testi ile ilgili açıklamalar aşă̆ıda verilmiştir.

\section{Okuduğunu anlama testi (OAT)}

Araştırmada öğrencilerin okuduğunu anlama becerilerini belirlemek için Karabay ve Kuşdemir Kayıran'ın (2010) geliştirdiği “Okuduğunu Anlama Başarı Testi”, yazarlardan izin alınarak kullanılmıştır. OAT, farklı türdeki yedi metin ve dört seçenekli çoktan seçmeli 25 sorudan oluşmakta ve 0-1 şeklinde puanlanmaktadır. OAT maddelerinin güçlük değerleri, 0,21 ile 0,85 , ayırıcılık değerleri ise 0,20 ile 0,53 arasındadır. Testin KR 20 güvenirlik katsayıs1 0,80 , 
ortalama güçlüğü 0,65 'tir. Bu çalışma kapsamında OAT, deneysel işlem öncesinde deney ve kontrol grubundaki 69 öğrenciye uygulanmıştır. Uygulamadan elde edilen puanların test analizi sonucunda testin ortalama güçlügü 0,62 , KR-20 güvenirlik katsayısı 0,82 olarak hesaplanmıştır.

\section{Kavram öğrenme testi (KÖT)}

Araştırmada kullanılan zarf kavramı ile ilgili KÖT'ü geliştirme işlemleri şöyledir:

1. İlk olarak zarf kavramı, hem zarf kavramılla ilgili kaynaklardan (Banguoğlu, 1995; Delice, 2017; Korkmaz, 2009; Özderi, 2010; Özel, 2018; Sayalı, 2009; Usta, 2010) hem de kavram öğretimi kaynaklarından yararlanılarak (Karataş Coşkun, 2011; Martorella, 1986; Klausmeier, 1990) kavram analizi yöntemi ile analiz edilmiştir. Analiz sonucunda zarf kavramının ve zarf türlerinin adı ve tanımı, ayırt edici özellikleri, ayırt edici olmayan özellikleri, örnekleri ve örnek olmayanları ile ilgili çoktan seçmeli dört seçenekli 50 maddelik bir test hazırlanmıştır. Hazırlanan test, uzman görüş formu ile birlikte, yedi Türkçe öğretmeni ve eğitim programları ve öğretim alanında doktora eğitimine sahip iki doktor öğretim üyesi tarafından kapsam geçerliği açısından incelenerek dörtlü dereceleme ölçeğine göre değerlendirilmiştir. Aynı zamanda iki doktor öğretim üyesi, araştırmacıların oluşturduğu belirtke tablosunu kullanarak test maddelerini ikinci kez incelemiştir. Belirtke tablosundaki kazanımlardan biri Türkçe dersi öğretim programından (2018) alınırken, diğer beş kazanım araştırmacılar tarafından yazılmıştır. Uzmanlardan alınan düzeltmeler ve öneriler doğrultusunda bir soru testten çıkartılmıştır. Sonrasında A ve B olarak iki form oluşturulmuştur. A formu 25, B formu 24 sorudan oluşan 49 çoktan seçmeli testin ön denemesi yapılmıştır.

2. Test, ön denemede aynı okuldaki sekizinci sınıf öğrencilerine uygulanmıştır. A formunu 134, B formunu 137 öğrenci yanıtlamıştır.

3. Ön denemede elde edilen puanlar üzerinden, her maddenin madde güçlük derecesi (pj), standart sapması (sj), ayırıcılık derecesi (rjx) ve alt ve üst gruplar \%27'lik dilimler için bağımsız gruplar $\mathrm{t}$ testi değerleri hesaplanmıştır. Madde analizinde ayırıcılık derecesi 0,25 'in altında olan 11 madde testten çıkarılmıştır. Geriye kalan 38 madde arasından seçilen 30 maddelik nihai test deneysel işlemde ögrencilere uygulanmış, süreç sonunda testin madde ve test analizleri tekrar yapılmıştır. $\mathrm{Bu}$ analiz sonucunda madde ayırıcılık derecesi 0,30 'un altında olan dört madde, kapsam geçerliği korunarak testten çıkarılmıştır. Testteki 26 maddenin güçlük dereceleri (pj), 0,50 ile 0,88; ayırıcılık dereceleri (rjx), 0,33 ile 0,68 arasındadır. Alt ve üst gruplar \%27'lik dilimler için yapılan bağımsız gruplar $\mathrm{t}$ testi sonucunda tüm maddelerin anlamlılık değeri 0,05 'ten küçük bulunmuştur. 26 sorudan oluşan toplam test puanlarının ortalamas1 17,50; standart sapmas1 5,93; ortancas1 17,00 ; tepe değeri 13,00 ve ortalama güçlüğü 0,44 'tür. Bu değerlere göre ortalama ve ortanca değerinin birbirine çok yakın olduğu; tepe değer, ortalama ve ortancadan küçük olduğu için dağglımın sağa çarpık bir eğilim gösterdiği ve testin orta güçlükte olduğu belirtilebilir. Testin KR-20 güvenirlik katsayıs1 0,88'dir. Bu değer, 0,70'ten büyük olduğundan testin güvenirliğinin yüksek olduğu ifade edilebilir (Kalayc1, 2006). KÖT’ten alınabilecek en yüksek puan 26, en düşük puan sıfırdır. KÖT'teki sorulardan 2'si hatırlama, 16'sı anlama, 5'i uygulama ve 3'ü analiz basamağındadır.

\section{Transfer testi}

Transfer testi, düzyazı ve şiir olmak üzere iki metinden oluşmaktadır. Metinler, zarf türlerinden her birinin en az bir örneğini kapsaması ve öğrencilerin düzeyine uygun olması ölçütlerine göre seçilmiştir. Düz metin, Ayşe Yamaç'ın (2010) "Dedemin Gizli Defteri” adlı kitabının bir bölümünden alınmıştır ve 107 kelimeden oluşmaktadır. Araştırmada zarf türlerinin tamamını barındıran bir şiire ulaşılamamıştır. Bu nedenle geçmiş yıllarda yedinci sınıf ders kitaplarında bulunan (MEB, 2014) ve içinde en fazla zarfa sahip olan Beşir Ayvazoğlu'nun "Bakardım Güneş Avuçlarımda" şiiri tercih edilmiştir. Transfer testi, beş Türkçe öğretmeninin görüşüne sunulmuş ve onlardan ikili dereceleme ölçeğine göre görüşlerini belirtmeleri istenmiştir. Beş 
uzmandan alınan geri bildirimler sonrasında şiir ve düzyazıdan oluşan transfer testine son şekli verilmiştir.

Transfer testi iki aşamalıdır. Birinci aşamada metinlerde zarf olan sözcük ya da sözcük gruplarının tam ve doğru belirlenmesi istenmiştir. İkinci aşamada öğrencilerden zarf türünün adını yazarak gerekçesini açıklamaları beklenmiştir. Transfer testinden elde edilen yanıtlar, araştırmacılar tarafından hazırlanan puanlama anahtarına göre puanlanmıştır (EK 1). Düzyazı metninde zarf türlerine ait 21 tane sözcük veya sözcük grubu bulunmaktadır. Cevap anahtarına göre düzyazı metnindeki tüm zarfları ve bu zarfların türlerini doğru şekilde belirleyip gerekçesini tam açıklayan bir öğrencinin alabileceği en yüksek puan 42, en düşük puan sıfırdır. Aynı şekilde şiirde öğrencilerin zarf olan sözcük ya da sözcük gruplarını, bunların türünü belirlemeleri ve gerekçesini açıklamaları istenmiştir. Şiirde zarf görevinde sekiz sözcük/sözcük grubu bulunmaktadır. Buna göre şiirdeki tüm zarfları ve bu zarfların türlerini doğru şekilde belirleyip gerekçesini tam açıklayan bir öğrencinin alabileceği en yüksek puan 16, en düşük puan sıfırdır. Transfer testinin puanlama güvenirliğini sağlamak amacıyla deney ve kontrol gruplarından rastgele seçilen 16 ögrencinin kağıdı araştırmanın birinci yazarı, ikinci yazarı ve bir Türkçe öğretmeni tarafından puanlama anahtarı kullanılarak puanlanmıştır. Daha sonra üç bağımsız puanlayıcının verdiği puanlar arasında Kendall uyum katsayısı hesaplanmıştır (Can, 2013). Elde edilen değer 1'e yakın olduğu için üç puanlayıcının puanlamaları arasında istatistiksel olarak anlamlı derecede uyum olduğu belirlenmiştir $\left(\mathrm{W}^{\mathrm{a}}=980, \mathrm{p}<0,01\right)$.

\section{İşlem}

Aşağıda deney ve kontrol grubunda gerçekleştirilen işlemlerle ilgili bilgiler verilmektedir.

\section{Deneysel işlem}

Çalışmada uygulanan deneysel işlem şöyledir:

1. Deneysel işlem öncesi çalışma grubunda yer almayan ve başka bir Türkçe öğretmeninin girdiği bir yedinci sınıf şubesindeki 32 öğrenci ile ön çalışma yapılmıştır. Ön çalışmada öğrencilerin çalışma kitapçığındaki alıştırmaları yapmakta zorlandıkları gözlenmiş ve bunun üzerine çalışma kitapçığına çözülmüş örnekler eklenmiştir. Ayrıca kavramın örnek ve örnek olmayanları ile ilgili açıklamaların öğrencileri sıktığı gözlendiğinden açıklama gerektiren örnek ve örnek olmayan sayısı azaltılarak öğrencilerin sözlü açıklamalarla derse aktif bir şekilde katılımının sağlanmasına karar verilmiştir.

2. Deneysel işlem için okul yönetiminin izni alınarak öğrencilerin haftalık ders programlarında yer alan Türkçe ders saatleri kullanılmıştır. İki yedinci sınıf şubesinden birinin Türkçe derslerinde deneysel işlem gerçekleştirilirken, diğer yedinci sınıf şubesinin Türkçe derslerinde kontrol grubunun öğretimi gerçekleştirilmiştir. Deneysel işlem sürecinde gruplardaki öğrencilerin sınıf değiştirme işlemleri; okul yönetiminin izni ve bilgisi dâhilinde, ögrencilerin ve diğer grubun ders öğretmeninin gönüllü katılımları ile yapılmıştır. Her iki grupta da öğretim, araştırmanın birinci yazarı tarafından gerçekleştirilmiştir.

3. Deneysel işlemde gruplara ilk olarak OAT ve ardından KÖT öntest olarak verilmiştir. Testler dağıtılmadan önce öğrencilere testi nasıl yanıtlayacaklarına ilişkin yönerge açılanmıştır. Her bir test için öğrencilere bir ders saati süre (40 dakika) verilmiştir. Bütün öğrenciler bu süre içerisinde testlerini tamamlamıştır.

4. Öntestler uygulandıktan sonra grupların ilk Türkçe dersinde deneysel işleme başlanmıştır. Deney grubunda örnek ayrıntılama stratejisi kullanılarak ders işlenirken, kontrol grubunda örnek ayrıntılama stratejisinin uygulanmadığı mevcut Türkçe dersi öğretim programına dayalı ögretime devam edilmiştir. Deney ve kontrol grubundaki öğrencilere zarf ve zarf türlerinin ayırt edici ve ayırt edici olmayan özellikleri sunularak eşit sayıda örnek 
verilmiştir. Fakat örnek ayrıntılama stratejisinde, örnekleri ve örnek olmayanları karşılaştırmayı içeren ayrıntılama etkinlikleri yer aldığı için kontrol grubundaki öğrencilere örnek olmayanlar sunulmamıştır. Her iki grupta da öğrenme-öğretim etkinlikleri yedi ders saati sürmüştür.

5. Uygulama bittikten sonra KÖT, sontest olarak tekrar verilmiştir. Sontestten sonraki Türkçe dersinde her iki gruba transfer testi uygulanmıştır. Transfer testi için öğrencilere iki ders saati süre verilmiştir. Sontestten üç hafta sonra kalıcılık testi uygulanmıştır.

\section{Deney grubunda kullanılan materyaller ve dersin işlenişi}

Deney grubunda zarf ve zarf türlerinin öğretiminde kullanılan materyalleri hazırlamak amacıyla kavram analizi yapılmıştır. Kavram analizinde zarf ve zarf türlerine ait "kavram adı ve tanımı, ayırt edici özellikler, ayırt edici olmayan özellikler, kavram hiyerarşisi (üst-alt-türdeş kavramların ilişkisi), kavramın örnekleri ve örnek olmayanları" ile ilgili elde edilen bilgiler temel alınarak çalışma kitapçığı, çalışma yaprakları ve powerpoint sunusu hazırlanmıştır. Hazırlanan çalışma kitapçığı, beş Türkçe öğretmenine sunulmuştur ve onların verdiği geri bildirimlere göre (örneklerin zorluk derecesi, her bir zarf türü ile ilgili farklı örneklerin verilmesi gibi) öğretim materyalleri yeniden düzenlenmiștir. Sonrasında bir ders planı hazırlanmıştır. Çalışma kitapçı̆̆ında zarf kavramı ile ilgili 10 örnek ve örnek olmayana yer verilmiştir. Zarf türlerinin her biri için üç örnek ve örnek olmayan kullanılmıştır.

Çalışma kitapçığı, deney grubundaki öğrenci sayısına göre çoğaltılarak öğrenme-öğretim etkinliklerine başlamadan önce onlara dağıtılmıştır. Öğrencilerden ad, soyadı ve öğrenci numaralarını kitapçıkta belirtilen yere yazmaları istenmiştir. Öğrenciler süreç boyunca aynı kitapçıkları kullanmışlardır. Kitapçıklar, her dersin sonunda toplanmış, bir sonraki derste öğrencilere tekrar dağıtılmıştır. Böylece kitapçıkların kontrol grubundaki öğrenciler tarafından edinilmesi önlenmiştir. Örnek ayrıntılama stratejisi, soru-cevap, anlatım, tartışma yöntemi ile işe koşulmuştur ve akıllı tahtadan açılan powerpoint sunusu ile ders işlenmiştir.

Örnek ayrıntılama stratejisi kapsamında öğrencilerden kavram şemasını incelemeleri ve görüşlerini belirtmeleri, eş zamanlı sunulan örnek ve örnek olmayanları karşılaştırmaları, kendilerine sunulan yeni örnek ve örnek olmayanları inceleyerek bunların örnek olup olmadığını nedenleriyle birlikte sözlü ve yazılı olarak belirtmeleri, çalışma yapraklarında verilen sözcükleri cümlede zarf veya zarf türüne uygun olarak kullanmaları, cümlede kullandığ 1 sözcüğün hangi zarf türü olduğunu belirlemeleri ve kendi örneklerini vermeleri istenmiştir. Uygulamada tüm öğrencilerin derse katılımını sağlamak amacıyla öğrencilere eşit söz hakkı verilmiştir. Her dersin sonunda öğrenciler, çalışma yapraklarıyla tekrar ve alıştırma yapmışlardır. Çalışma yapraklarında, öğrencilere birer adet çözülmüş örnek sunulmuş ve öğrenciler bunları inceledikten sonra alıştırmaları yapmışlardır. Bu sürede araştırmacı sınıfta dolaşarak öğrencilerin sorularını yanıtlamıştır ve her öğrenciye bireysel olarak geribildirim vermiştir. Yine öğrencilere “...niçin zarf kavramının örneğidir, ...zarf kavramının örneği olduğuna nasıl karar verdiniz? ...zarf kavramının örneği midir” gibi sorular tekrar yöneltilmiştir. Birinci araştırmac1, her uygulama sonrasında bu süreci uygulamada olduğu şekliyle araştırmacı günlüğüne kaydetmiştir.

\section{Kontrol grubunda kullanilan materyaller ve dersin işlenişi}

Kontrol grubundaki işlemlere deney grubuyla aynı zamanda başlanmıştır. Deney grubunda olduğu gibi OAT ve KÖT öntest olarak sunulmuştur. Sonrasında ilk Türkçe dersinde konu anlatımına başlanmıştır. Süreç boyunca anlatım ve soru-cevap yöntemi kullanılmıştır. Kontrol grubunda zarf kavramının öğretimi ile ilgili olarak, deney grubuyla eşit sayıda ve aynı örnekler kullanılmıştır, ancak örnek olmayanlar sunulmamıştır. Bunun dışında kavramların tanımları ve açıklamaları, deney grubunda verildiği şekilde sunulmuştur. Fakat kontrol grubundaki öğrenciler, kendi örneklerini vermemişlerdir, örneklerin neden örnek olup olmadığını açıklamamışlardır, örnekleri ve örnek olmayanları karşılaştırmamışlardır. Kontrol grubunda da öğrencilerin soruları araştırmacı tarafindan tek tek yanıtlanmıştır. 


\section{Müdahale sürecinde alınan etik önlemler}

Bu araştırmada Çukurova Üniversitesi Sosyal Bilimler Enstitüsü Etik Kurulu'ndan 30.09.2020 tarih 2020/20 sayılı karar ile gerekli izinler alınmıştır. Ayrıca deneysel uygulamada araştırma etiği açısından aşağıdaki önlemler alınmıştır:

1. Araştırmada deneysel işleme başlanmadan önce her iki gruptaki öğrencilere de bir araştırma projesinin yürütüleceği, bu projede kendilerinin de yer alacağ ve çalışmanın nasıl yürütüleceği hakkında bilgi verilmiştir. Ancak gruplar arasında doğabilecek herhangi bir etkileşimi önlemek amacıyla öğrencilere hangi grubun deney, hangi grubun kontrol grubu olduğuna dair hiçbir bilgi verilmemiştir.

2. Deney ve kontrol grubundaki öğrencilere süreç boyunca gösterecekleri performanstan dolay1 herhangi bir beklenti oluşturmamaları için devamlı bilimsel bir araştırma sürecinin özneleri oldukları ve gösterecekleri çabanın bilimsel araştırma açısından önemli olduğu vurgulanmıştır. Deney ve kontrol grubundaki öğrencilere olumlu pekiştireçlerin (aferin, çok güzel vb.) kullanımında eşit davranmaya özen gösterilmiştir.

3. Öğrencilerin araştırmaya gönüllü katılımları esas alınmıştır. Süreç başlamadan önce, süreç sırasında deneysel işlemden çıkmak isteyen öğrencilere çıkabilecekleri, sözlü olarak ifade edilmiştir.

4. Araştırmada öğrencilerin kişisel bilgileri sadece bu çalışmada kullanılmıştır. Ham veriler işlenirken öğrencilerin isimleri Ö1, Ö2 vb... şeklinde kodlanmıştır.

\section{Verilerin analizi}

Araştırmada deney ve kontrol gruplarını OAT ve KÖT öntest toplam puanları arasında anlamlı bir fark olup olmadığ 1 bağımsız gruplar $t$ testi ile incelenmiştir. Deney ve kontrol gruplarının sontest, transfer testi ve kalıcılık testi toplam başarı puanları arasında anlamlı farklılık olup olmadığı ANCOVA ile belirlenmiştir. ANCOVA için öncelikle her bir ölçümde gruplar içi regresyon doğrularının eğimlerinin eşitliği sontest $(\mathrm{F}(2-54)=0,77, \mathrm{p}>0,05)$, transfer testi $(\mathrm{F}(2$ $54)=0,12, p>0,05)$ ve kalıcılık testi $(F(2-54)=0,08, p>0,05)$ için hesaplanmıştır. Sonrasında varyansların homojenliği sayıltısı Levene $F$ testi ile sontest $(F(2-54)=0,25, p>0,05)$, transfer testi $(\mathrm{F}(1-56)=2,44, \mathrm{p}>0,05)$ ve kalıcılık testi için $(\mathrm{F}(1-56)=3,11, \mathrm{p}>0,05)$ incelenmiştir.

Analizlerde normallik sayıltısı Kolmogorov-Smirnov testiyle KÖT sontest $\left(\mathrm{x}^{2}=0,106, \mathrm{sd}=60\right.$, $\mathrm{p}=0,08)$, transfer testi $\left(\mathrm{x}^{2}=0,093, \mathrm{sd}=60, \mathrm{p}=0,20\right)$ ve kalıc1lik testi için $\left(\mathrm{x}^{2}=0,093, \mathrm{sd}=60, \mathrm{p}=\right.$ $0,20)$ incelenmiş ve puanların normal dağılım gösterdiği saptanmıştır. ANCOVA'nın uygulandığı tüm ölçümler için kontrol altına alınan ortak değişkenler ile bağımlı değişkenler arasında anlamlı bir ilişki olup olmadığı Pearson korelasyonu ile test edilmiştir (Kalayc1, 2006). Ortak değişkenler ile bağımlı değişkenler arasında sontest $(r=0,73, p=0,00)$, transfer testi $(r=$ $0,76, p=0,00)$ ve kalıc1lı için $(r=0,93, p=0,00)$ pozitif yönde ve anlamlı bir ilişkinin olduğu belirlenmiştir. Araştırmada bağımsız değişkenin bağımlı değişkenlerdeki toplam varyansı açılayabilme gücü etki büyüklügü (eta-kare, ๆ2) değeri hesaplanarak belirlenmiştir. Büyüköztürk'ün $(2007$, s.48) belirttiği gibi “ $0,01,0,06$ ve 0,14 düzeyindeki etki büyüklüğü değerleri, sırasıyla küçük, orta ve geniş etki büyüklügüu” olarak yorumlanmaktadır. Elde edilen bulguların yorumlanmasında 0,05 anlamlılık düzeyi kabul edilmiştir.

\section{Bulgular \\ Araştırmada elde edilen bulgular araştırma soruları doğrultusunda sırasıyla aşağıda verilmektedir.}

\section{Araştırmanın birinci alt amacına ait bulgular}

$\mathrm{Bu}$ çalışmada deney ve kontrol grubunun KÖT ve OAT öntest toplam başarı puanları kontrol edildiğinde, KÖT sontest düzeltilmiş puanlarının örnek ayrıntılama stratejisinin kullanıldığ1 deney grubu lehine anlamlı farklılık gösterip göstermediği ile ilgili OAT ve KÖT öntest ve sontest toplam başarı puanlarına ilişkin aritmetik ortalama, standart sapma, düzeltilmiş ortalama ve ANCOVA sonuçları Tablo 3’te verilmiştir. 
Zarf Kavramının Öğretiminde Örnek Ayrıntılama Stratejisinin Kavram Öğrenmeye, Kalıcılığa ve Transfere Etkisi

Tablo 3

Deney ve Kontrol Grubunun KÖT ve OAT Öntest-Sontest Toplam Başarı Puanlarının Aritmetik Ortalama, standart Sapma, Düzeltilmiş Ortalama ve ANCOVA Sonuçları

\begin{tabular}{|c|c|c|c|c|c|c|c|c|}
\hline \multirow{2}{*}{ Gruplar } & \multirow{2}{*}{$\mathrm{N}$} & \multirow{2}{*}{ Testler } & \multicolumn{3}{|c|}{ Toplam Başarı Puanı } & \multirow{2}{*}{$\mathrm{F}$} & \multirow[b]{2}{*}{$\mathrm{p}$} & \multirow{2}{*}{$\eta 2$} \\
\hline & & & $\overline{\mathrm{X}}$ & SS & Düzelt. Ort. & & & \\
\hline \multirow[t]{3}{*}{ Deney } & 30 & KÖT Öntest & 12,63 & 5,04 & - & 59,363 & $0,00^{*}$ & 0,51 \\
\hline & & OAT Öntest & 18,00 & 3,91 & - & & & \\
\hline & & Sontest & 20,36 & 4,91 & 20,24 & & & \\
\hline \multirow[t]{3}{*}{ Kontrol } & 30 & KÖT Öntest & 12,73 & 4,59 & - & & & \\
\hline & & OAT Öntest & 16,90 & 4,70 & - & & & \\
\hline & & Sontest & 14,63 & 5,51 & 14,76 & & & \\
\hline
\end{tabular}

$* \mathrm{p}<0,05$.

Tablo 3'e göre deney ve kontrol grubundaki öğrencilerin, sontest KÖT toplam başarı puanlarının ortalaması deney grubunda $\bar{X}=20,36$, kontrol grubunda $\bar{X}=14,63$ iken, kontrol edilen öntestlere göre düzeltilmiş ortalama, deney grubunda $\bar{X}=20,24$; kontrol grubunda $\bar{X}=$ 14,76'dır. Gruplar arasında gözlenen farkın anlamlılığını belirlemek için yapılan ANCOVA sonucunda KÖT ve OAT öntest toplam puanları kontrol edildiğinde, KÖT sontest düzeltilmiş ortalama puanları açısından gruplama ana etkisinin deney grubu lehine anlamlı olduğu saptanmıştır $(F(1-56)=59,363, p<0,05)$. Tablo 3 'teki etki büyüklüğü değerine göre $(\eta 2=0,51)$ örnek ayrıntılama stratejisi KÖT sontest puanlarındaki değişkenliğin \%51'ini açıklayabilmektedir.

\section{Araştırmanın ikinci alt amacına yönelik bulgular}

Araştırmada deney ve kontrol grubunun KÖT sontest toplam başarı puanları kontrol edildiğinde, kalıcılık testi ve transfer testi düzeltilmiş puanlarının örnek ayrıntılama stratejisinin uygulandığı deney grubu lehine anlamlı farklılık gösterip göstermediğiyle ilgili sonuçlar Tablo 4'tedir. Tablo 4'e göre kalıcılık testi toplam başarı puanları ortalaması deney grubunda $\overline{\mathrm{X}}=18,76$, kontrol grubunda $\overline{\mathrm{X}}=13,26$ 'dır. Kontrol edilen sontest puanlarına göre düzeltilmiş ortalamalar deney grubunda $\overline{\mathrm{X}}=16,08$; kontrol grubunda $\overline{\mathrm{X}}=15,95^{\prime}$ 'dir. Yapılan ANCOVA sonucunda ise, kalıcılık testi düzeltilmiş ortalama puanları açısından gruplama ana etkisinin anlamlı olmadığı tespit edilmiştir $(\mathrm{F}(1-57)=0,043, \mathrm{p}>0,05)$. Tablo 4 'teki etki büyüklüğü değeri incelendiğinde $(\eta 2=0,00)$ örnek ayrıntılama stratejisinin kalıcılık testi puanlarındaki değişkenliği açıklama gücüne sahip olmadığı görülmektedir.

Tablo 4'e göre transfer testi toplam başarı puanları ortalaması deney grubunda $\overline{\mathrm{X}}=20,11$, kontrol grubunda $\overline{\mathrm{X}}=11,06$ 'dır. Kontrol edilen sontest puanlarına göre düzeltilmiş ortalamalar1, deney grubunda $\overline{\mathrm{X}}=17,09$; kontrol grubunda $\overline{\mathrm{X}}=14,08$ 'dir. ANCOVA sonucunda, transfer testi düzeltilmiş ortalama puanları açısından gruplama ana etkisi anlamlı bulunmamıştır $(F(1-57)=3,042, p>0,05)$. Tablo 4 'teki etki büyüklüğü değerine göre $(\eta 2=0,05)$ örnek ayrıntılama stratejisinin transfer testi puanlarındaki değişkenliği açıklama gücünün olmadığı belirtilebilir. 
Nergiz ve Akbulut Taş

Tablo 4

Deney ve Kontrol Grubunun KÖT Sontest-Kalıcılık Testi, KÖT Sontest-Transfer Testi Toplam Başarı Puanlarının Aritmetik Ortalama, Standart Sapma, Düzeltilmiş Ortalama ve ANCOVA Sonuçları

\begin{tabular}{|c|c|c|c|c|c|c|c|c|}
\hline \multirow[b]{2}{*}{ Gruplar } & \multirow[b]{2}{*}{$\mathrm{N}$} & \multirow{2}{*}{ Testler } & \multicolumn{3}{|c|}{ Toplam Başarı Puanı } & \multirow[b]{2}{*}{$\mathrm{F}$} & \multirow[b]{2}{*}{$\mathrm{p}$} & \multirow[b]{2}{*}{$\eta 2$} \\
\hline & & & $\bar{X}$ & SS & Düzelt. Ort. & & & \\
\hline \multirow[t]{2}{*}{ Deney } & 30 & Sontest & 20,36 & 4,91 & - & 0,043 & 0,836 & 0,00 \\
\hline & & Kalıcilık & 18,76 & 5,51 & 16,08 & & & \\
\hline \multirow[t]{2}{*}{ Kontrol } & 30 & Sontest & 14,63 & 5,51 & - & & & \\
\hline & & Kalıcilık & 13,26 & 5,17 & 15,95 & & & \\
\hline \multirow[t]{2}{*}{ Deney } & 30 & Sontest & 20,36 & 4,91 & - & 3,042 & 0,087 & 0,05 \\
\hline & & Transfer & 20,11 & 8,80 & 17,09 & & & \\
\hline \multirow[t]{2}{*}{ Kontrol } & 30 & Sontest & 14,63 & 5,51 & & & & \\
\hline & & Transfer & 11,06 & 7,07 & 14,08 & & & \\
\hline
\end{tabular}

\section{Tartışma, Sonuç ve Öneriler}

$\mathrm{Bu}$ çalışmada yedinci sınıf öğrencilerine zarf kavramının öğretiminde uygulanan örnek ayrıntılama stratejisinin kavram öğrenme başarısına, kalıcılığa ve transfere etkisi incelenmiştir. Araştırmada deney ve kontrol gruplarına uygulanan OAT ve KÖT öntestleri toplam puanları kontrol edildiğinde sontest düzeltilmiş ortalama puanları arasında deney grubu lehine istatistiksel olarak anlamlı bir farklılık belirlenmiştir. Buna göre deney grubunda uygulanan örnek ayrıntılama stratejisinin sontest için etkili olduğu, bu grupta yer alan öğrencilerin zarf kavramı ve zarf türleri ile ilgili bilgileri edindiği belirtilebilir.

Kavramlar, anlamsal özellikleri yansıtan zihinsel temsillerdir ve soyutturlar (Pesonen, 2002). Örnekler ise kavrama ait anlamsal özellikleri taşıyan, bir kavramın ne olduğunu ya da olmadığını göstererek kavramın sınırlarını çizen somutlardır. Örnekler, kavramın ayırt edici özelliklerini ve aynı zamanda bazı ayırt edici olmayan özelliklerini gösterdiği için, kavramın tanımının ve özelliklerinin daha etkili öğrenilmesini kolaylaştırabilir (Corral ve Carpenter, 2020). Kavram öğretiminde örneklerin sunulmas1, öğrencilerin kavramlarla ilgili uygun ve yararlı zihinsel temsiller oluşturmalarına yardım etmektedir (Bolkan ve Goodboy, 2019) ve anlamsal özellikleri daha açık ve anlamlı hale getirmektedir. Deney grubundaki öğrencilere kavramın örnekleri ile birlikte örnek olmayanları da eş zamanlı sunulmuş, örnekler ile örnek olmayanlar arasındaki farklılıklar yazılı ve sözlü olarak açıklanmıştır. Aynı şekilde öğrencilerin kendilerine verilen örnek ve örnek olmayanları nedenleriyle birlikte açıklamaları, verilen zarf sözcük ya da sözcük gruplarını bir cümlede kullanmaları, kendilerinin örnek vermeleri ve verdikleri örneklerin neden örnek olup olmadığını açıklamaları, deney grubu lehine anlamlı farkın çıkmasında etkili olmuş olabilir. Bir kavramın öğretiminde kavramın örneklerinin ve örnek olmayanlarının eşleştirilerek sunulması, benzerlik ve farklılık yönünden karşılaştırmayı gerektirdiği için, öğrencilerin doğru bir şekilde anlamlandırmasını ve doğru sınıflamalar yapmasını sağlamaktadır (Klausmeier, 1990; Park, 1984; Tennyson ve Cocchiarella, 1986).

Bu çalışmadaki deneysel işlemde, sadece örneklerin ve örnek olmayanların sunulmasıyla yetinilmemiş, ayrıca örnek-özellik ilişkisini kurmayı gerektiren ayrıntılayıcı etkinliklerle öğrencilerin sunulan bilgileri detaylandırmaları sağlanmıştır. Ayrıntılama ile öğrenci bilginin gerçek anlamından uzaklaşmadan onu belleğine kaydeder ve bilişsel şemasına yeni yollar ekleyerek bilişsel yapısını güçlendirir (Hannon, 2012). Örneğin Roelle ve diğerleri (2017), örnek temelli öğrenmede çözülmüş örneklerin, öğrencilerin bilimsel açıklamalarını artırdığını 
belirlemişlerdir. $\mathrm{Bu}$ araştırmada kavramların tanımı ve özellikleriyle birlikte örnekler ve örnek olmayanlar öğretmen tarafindan düzenlenerek sunulmuştur, örneklerin ve örnek olmayanların neden örnek olup olmadığı ile ilgili açıklamalar yapıldıktan sonra öğrencilere alıştırma ve uygulama yaptırılmıştır. Dolayısıyla deney grubunun sontest düzeltilmiş ortalamalarının kontrol grubuna göre daha yüksek olması, süreçte öğretmen tarafindan yapılan ayrıntılamaların öğrencilerin yaptıkları ayrıntılayıcı etkinliklerle desteklenmesinin bir sonucu olabilir. Bolkan ve Goodboy (2019), öğretmen tarafından sunulan örneklere dayalı öğrenme koşulunun, sadece öğrencilerin kendi örneklerini verdikleri öğrenme koşuluna göre daha anlamlı bir fark oluşturduğunu; öğretmen tarafından sunulan örneklerin öğrencilerin daha tutarlı bir zihinsel model oluşturarak ders materyalini düzenlemelerine yardım ettiğini saptamışlardır. Rawson ve diğerleri (2015) de gerçek yaşamdan seçilen açıklayıcı örnekler üzerinde çalışan ve ayrıntılayan ögrencilerin, yalnızca tanımları okuyan öğrencilere kıyasla sınıflama testinde daha iyi performans gösterdiklerini saptamışlardır.

Araştırmada kontrol grubundaki öğrencilerin kavram öğrenme sontest toplam başarı puanları ortalamasında da bir artış gözlenmiştir. Kontrol grubunda zarf kavramı ve zarf türleri ile ilgili kavram analizi sonucu elde edilen bilgiler (kavramın adı ve tanımı, ayırt edici özellikleri, ayırt edici olmayan özellikleri, kavram şeması ve örnekleri) sunulmuştur ancak sadece ayrıntılama etkinlikleri gerçekleştirilmemiştir. Bu sonuca göre kavramın tanımı, özellikleri ve örnekleri öğretmen tarafindan doğru bir şekilde verildiğinde, öğrencilerin kavrama ait bilgileri edinebilecekleri belirtilebilir.

$\mathrm{Bu}$ araştırma sonucunda deney ve kontrol grubunun sontest toplam başarı puanları kontrol edildiğinde, deney grubunun kalıc1lık testi ortalamasının kontrol grubunun ortalamasına göre yüksek olduğu, ancak deney ve kontrol grubunun düzeltilmiş ortalama puanları arasında istatiksel olarak anlamlı bir farklılık olmadığ kontrol grubundaki öğrencilerde de bir öğrenmenin gerçekleşmiş olması ve bu öğrenmenin kalıcılık puanlarını etkilemesi olarak yorumlanabilir. Ayrıca deney grubundaki öğrencilerin kalıcılık testinin uygulanmasına kadar geçen zaman diliminde öğrendiklerini tekrar edip etmemesi de böyle bir sonucun çıkmasında etkili olmuş olabilir. Çünkü öğrenilen bilgi ve becerilerin belli aralıklarla tekrar edilmesi davranışın kalıcılığını kolaylaştırmaktadır (Dunlosky vd., 2013). Bunun yanında deney grubunda kullanılan ayrıntılama etkinlikleri, öğrenilenlerin kalıcılığını sağlamada yetersiz kalmış olabilir. Yine kontrol grubundaki öğrencilerle örnek ayrıntılama etkinlikleri yapılmamış olsa da zarf ve zarf türleri ile ilgili verilen bilgilerin düzenlenerek sunulmuş olması, öğretmenin sunduğu doğru örnekleri sınıfta öğrenmiş olmaları kontrol grubunda öğrenmeyi olumlu yönde etkilemiş olabilir. Hannon'un (2012) da ifade ettiği gibi öğrencilerin bir bilgiyi öğrenmesi ve bellekte kalıcı bir şekilde saklaması, görevin ne kadar iyi gerçekleştirildiğine, öğrenilen materyal ile test edilen materyalin içeriğinin örtüşme derecesine ve öğrenilecek olan materyalin doğasına ve düzenlemesine bağlıdır.

Dahası örnek ayrıntılama stratejisinin etkisi ile ilgili farklı sonuçlar ortaya koyan çalışmalar da bulunmaktadır. Örneğin Rawson ve Dunlosky (2016), bildirimsel kavramları (declarative concepts) öğrenmede öğrencilerin oluşturduğu örneklerin, orta düzeyde ilerleme sağladığını saptamışlardır. Zamary ve Rawson (2018a), öğretmenin sunduğu örneklerin, öğrencilerin oluşturduğu örneklerden daha etkili olduğunu; fakat bu ikisinin birlikte kullanıldığ 1 grubun, diğer iki gruba göre istatistiksel olarak çok küçük ve önemsiz bir üstünlük gösterdiğini saptamışlardır. Zamary ve Rawson (2018b) ise öğretmenin sunduğu örneklerle çalışan grupla, eksik bırakılan çözülmüş örneklerle çalışan grubun sontest performanslarının benzer olduğunu belirlemişlerdir. Dornisch ve diğerleri (2011) de sorgulayıcı ayrıntılama stratejisinin (elaborative interrogation strategy) diğer üretici öğrenme stratejilerine (generative learning strategies) göre etkisini test ettikleri araştırmada yüksek ve düşük başarılı öğrenenlerin sontest ve kalıcılık testlerinde anlamlı farklılık saptayamamışlardır. Dornisch ve diğerleri, sorgulayıcı ayrıntılama ile diğer ayrıntılama stratejileri arasında anlamlı farklılık çıkmamasını, öğrencilerin 
strateji kullanma yetenekleri, ön bilgileri, metin yapısı, strateji kullanımı konusunda sağlanan öğretim desteği ve yeterli uygulamanın olup olmaması gibi etkenlerden kaynaklanabileceğini belirtmişlerdir.

Bu çalışmada grupların sontest toplam puanları kontrol edildiğinde, transfer testi düzeltilmiş ortalama puanları arasında deney grubu lehine istatiksel olarak anlamlı farklılık saptanmamıştır. Transfer testinde, deney ve kontrol grubu arasında anlamlı farklılık gözlenmemiş olsa da deney grubundaki öğrencilerin kontrol grubundaki öğrencilere göre daha fazla ayrıntı içeren, tam ve doğru açıklamalar yaptıkları belirlenmiştir. Aşağıda deney ve kontrol grubundaki öğrencilerin transfer testinde yaptıkları açıklamalara örnekler sunulmuştur:

Örnek cümle: Kızlarla da çok iyi anlaşırdık.

D1: Iyi: Durum zarfidır. Çünkü anlaşmak fiilinin nasıl yapıldığını belirtmektedir.

D1: Çok: Miktar zarfidır. Çünkü iyi zarfinın ne kadar olduğunu belirtmektedir.

D2: L̀yi: Durum zarfidır. Anlaşmak fiilinin nasıl olduğunu belirtir.

D2: Çok: Miktar zarfidır. Lyi zarfinın anlamını etkiler.

K1: Çok iyi: Miktar zarfidır. Nasıl sorusunu yanıtllyor.

K2: Çok iyi: Durum zarfidır. Çünkü anlaşmak fiilini etkiler.

Deneysel işlem süresince öğrencilere zarf ve zarf türleri sadece örnek cümleler içinde sunulmuştur. Kavram başarı testinde de öğrenciler seçenekler içinden doğru cevabı seçmişlerdir. Yine ögrencilerin girdikleri sınavların genelinde çoktan seçmeli sorular kullanılmaktadır. Transfer testinde ise kendilerine verilen bir metin içinden zarfı bulmaları ve bu zarfın türünü doğru belirleyerek nedenini açıklamaları istenmiştir. Dolayısıyla bir metinde yer alan zarfi bulmak, öğrendiklerini aktarmak öğrencilere farklı ve zor gelmiş olabilir. Nitekim Mayer (1980) ayrıntılamaların, uzak transfer görevlerinden daha çok (orijinal problem çözme gibi) yakın transfer görevlerinde (sınıflama görevi gibi) daha etkili olduğunu tespit etmiştir. Ayrıca bu çalışmada transfer toplam puanları metin türü ayrımı yapılmaksızın elde edilmiştir. Oysa öğrencilerin düzyazıdaki zarfları ve türlerini, şiirdekine göre daha doğru belirleyebildikleri gözlenmiş̧tir. Şiirdeki zarfları ve türlerini belirleme puanları, her iki gruptaki öğrenciler için de düzyazıya göre daha düşüktü. Transfer testinde farklı metin türlerinin kullanılması ve bunların anlamlandırılmasının farklı bilişsel işlemler gerektirmesi, böyle bir sonucun çıkmasının nedeni olabilir. Nitekim metin türüne göre farklı üstbilişsel okuma stratejilerinin kullanılması gerektiğini Dilidüzgün, Çetinkaya Edizer, Ak Başoğul ve Karagöz, (2019) şöyle ifade etmişlerdir;

"Dilbilgisel ilişkileri kestirme/bağlayıcıları tanıma, sözcükleri parçalama ve sınıflandırma gibi dilsel yetilerle ilgili stratejiler her metin türü için eleştirel okumayı gerektirmiştir; ancak dil kullanımı ile bağdaştırılacak sözcüklerle ilişkilendirme stratejisinde türler, okuma yöntem-teknikleri bağlamında farklılık göstermektedirler. Öykü tahmin ederek, eleştirel, özetleyerek ve metinlerle ilişkilendirme; şiir eleştirel; makale ise işaretleyerek ve tartışarak okumayı gerekli kılmaktadır" (s.181).

Özetle, bu araştırmada elde edilen sonuçlar bir bütün olarak değerlendirildiğinde deney ve kontrol grubundaki öğrencilerin KÖT ve OAT öntest toplam puanları kontrol edildiğinde, kavram öğrenme sontest düzeltilmiş ortalamaları arasında deney grubu lehine anlamlı bir farklılık saptanırken; sontest toplam başarı puanları kontrol edildiğinde, kalıcılık testi ve transfer testi düzeltilmiş ortalamaları arasında deney grubu lehine anlamlı bir farklılık bulunamamıştır. $\mathrm{Bu}$ araştırmada ulaşılan sonuçlara dayalı olarak uygulamaya dönük ve ileride yapılacak çalışmalar için aşağıdaki öneriler dile getirilebilir:

- Araştırmada deney grubundaki öğrenciler, çalışma kitapçı̆̆ındaki örneklerden ve örnek olmayanlardan yararlanabilmişlerdir. Kitapçıklardaki örnekler ve örnek olmayanlar, 
kavram analizi yapılarak belirlenmiştir. Bu örneklerin ve örnek olmayanların çeşitlilik göstermesine dikkat edilmiştir. Dolayısıyla öğretim sürecinde sunulan örnekler analiz edilerek seçilebilir, bu örneklerin çeşitlilik göstermesine, örnek ve örnek olmayanların eşleştirilerek sunulmasına dikkat edilebilir.

- Araştırmadan elde edilen sonuçlara göre örnek ayrıntılama stratejisinin kavram öğrenmeyi kısmen de olsa olumlu yönde etkilediği belirlenmiştir. Alanyazında örnek ayrıntılama stratejisinin kavram öğrenmeye etkisi ile ilgili farklı sonuçlar rapor edilmektedir. Dolayısıyla kuramsal olarak örnek ayrıntılama stratejisinin yararı ve önemi açıkça dile getirilse de gerçek sınıf ortamındaki öğrenme sürecinde örnek ayrıntılama stratejisinin kullanımına etki eden faktörler (ön bilgi, metin düzenlemesi, metin türü, ders çalı̧̧ma becerileri, bilişsel farkındalık becerileri, derse yönelik tutum vb.) başka deneysel çalışmalarda detaylı incelenebilir. Ayrıca bu çalışmada deney ve kontrol grubundaki öğrencilere verilen geribildirimin etkisi incelenmemiştir. Buna karşılık bazı çalışmalarda ayrıntılayıcı geribildirimin ve örnek ayrıntılamanın (Finn vd., 2018), doğru ve yanlış örneklerinin birlikte sunulmasının ve ayrıntılayıcı geribildirimin (Corral ve Carpenter, 2020) kavram öğrenmeyi anlamlı bir şekilde etkilediği rapor edilmektedir. Yapılacak diğer çalı̧̧malarda farklı türdeki ayrıntılama stratejileriyle (yazar tarafından üretilen/öğrenci tarafından üretilen ayrıntılamalar; örnek ayrıntılama, farkı ilişkisel işleme) birlikte geri bildirimin etkisi incelenebilir.

- Bu çalışma ortaokul yedinci sınıf öğrencileri ile yapılmıştır. Farklı sınıf seviyelerine de uygulanabilir. Yine çalışma Türkçe dersi konularından zarf kavramı ile ilgilidir. Aynı alanın farklı konularında ya da farklı bir alanda da çalışmalar gerçekleştirilebilir.

\section{Etik Kurul Onay Bilgileri}

$\mathrm{Bu}$ araştırma, Çukurova Üniversitesi Sosyal Bilimler Enstitüsü Etik Kurulu'nun 30.09.2020 tarih ve 2020/20 sayılı kararı ile araştırma ve yayın etiğine uygun olarak gerçekleştirilmiştir.

\section{Çıkar Çatış̧ması}

Yazarlar tarafindan herhangi bir çıkar çatışmasının olmadığı beyan edilmiştir.

\section{Finansal Destek}

$\mathrm{Bu}$ çalışmaya Çukurova Üniversitesi Bilimsel Araştırma Fonu (Proje No: SYL-2017-8652) tarafindan finansal destek sağlanmıştır.

\section{Kaynaklar}

Akbulut Taş, M. ve Karataş Coşkun, M. (2012). Öğretim hedefleri ünitesindeki bilişsel alanda davranışsal amaç kavramının öğretiminde sunulan örneklerin çeşitliliğinin değerlendirilmesi. Türk Eğitim Bilimleri Dergisi, 10(3), 541-583.

Akyol, H. (2005). Türkçe ilk okuma yazma ögretimi. Ankara: Pegem A Yayınları.

Alkan, S. ve Güven, B. (2018). Ders kitaplarında kullanılan örnek türlerinin analizi: Limit konusu. Türk Bilgisayar ve Matematik Eğitimi Dergisi, 9(1), 147-169.

Banguoğlu, T. (2015). Türkçenin grameri. Ankara: Türk Dil Kurumu Yayınları.

Baştürk Şahin, B. N., Şahin, G. ve Tapan Broutin, M. S. (2017). Didaktik durumlar teorisi 1şı̆̆ında asal sayılar kavramının öğretimi: Bir eylem araştırması. Necatibey Eğitim Fakültesi Elektronik Fen ve Matematik Eğitimi Dergisi, 11(2), 156-171.

Bayram, B. (2015). 5E modelinin 6. sınıf dil bilgisi öğretiminde başarıya, akademik motivasyona ve kalıcılığa etkisi (Doktora tezi). https://tez.yok.gov.tr/UlusalTez Merkezi/'nden erişilmiştir (Tez No. 418260). 
Beydoğan, H. Ö., \& Hayran, Z. (2015). The effect of multimedia-based learning on the concept learning levels and attitudes of students. Eurasian Journal of Educational Research, 60, 261-280. doi: 10.14689/ejer.2015.60.14

Bilgin, D. (2018). Türkçe dersinde bulmaca ile kavram öğretiminin öğrenci başarısına ve derse karşı tutuma etkisi (Yüksek lisans tezi). https://tez.yok.gov.tr/UlusalTezMerkezi/'nden erişilmiştir (Tez No. 509389).

Bolat, Y. ve Dolapçığlu, S. (2020). Kavram öğretimi sürecinin "bil, anla, yap" boyutları bağlamında değerlendirilmesi. Bolu Abant İzzet Baysal Üniversitesi Eğitim Fakültesi Dergisi, 20(1), 61-80. doi: 10.17240/aibuefd.2020.20.52925-513943

Bolkan, S., \& Goodboy, A. K. (2019). Examples and the facilitation of student learning: Should instructors provide examples or should students generate their own? Communication Education, 68(3), 287-307. doi: 10.1080/03634523.2019.1602275

Büyüköztürk, Ş. (2001). Deneysel desenler. Ankara: Pegem A Yayınları.

Büyüköztürk, Ş. (2007). Sosyal bilimler için veri analizi el kitabı. Ankara: Pegem A Yayınları.

Can, A. (2013). SPSS ile bilimsel araştırma sürecinde nicel veri analizi. Ankara: Pegem A Yayınları.

Catrambone, R., \& Yuasa, M. (2006). Acquisition of procedures: The effects of example elaborations and active learning exercises. Learning and Instruction, 16, 139-153.

Cevher, T. Y. (2019). Öge gösterim kuramına dayalı kavram ögretiminin ortaokul 7. Sinlf ögrencilerinin Türkçe dersindeki başarılarına etkisi (Yüksek lisans tezi). https://tez.yok.gov.tr/UlusalTezMerkezi/'nden erişilmiştir (Tez No. 612537).

Charney, D. H., \& Reder, L. M. (1986). Initial skill learning: An analysis of how elaborations facilitate the three components. Technical Report No. ONR-86-1. Carnegie-Menion University, Pittsburgh.

Corral, D., \& Carpenter, S. K. (2020). Facilitating transfer through incorrect examples and explanatory feedback. Quarterly Journal of Experimental Psychology, 73(9), 13401359. doi: $10.1177 / 1747021820909454$

Çakar, E. (2013). Fen ve teknoloji dersinde araştırmaya dayal öğrenmenin öğrencilerin erişilerine, kavram ögrenmelerine, üstbiliş, farkındalıklarına ve fen ve teknoloji dersine yönelik tutumlarına etkisi (Doktora tezi). https://tez.yok.gov.tr/UlusalTezMerkezi/'nden erişilmiştir (Tez No. 337465).

Çavumirza, E. (2018). Model ile fen öğretiminin 8. sinıf öğrencilerinin başarıları, eleştirel düşünme ĕgilimleri, tutumlarına ve kavram ögrenmelerine etkisi (Yüksek lisans tezi). https://tez.yok.gov.tr/UlusalTezMerkezi/'nden erişilmiştir (Tez No. 516233).

Çocuk, H. E. (2012). İlköğretim ikinci kademe Türkçe ders kitapları bağlamında sıfat öğretiminde aşamalılık sorunu (Yüksek lisans tezi). https://tez.yok.gov.tr/UlusalTez Merkezi/'nden erişilmiştir (Tez No. 319632).

Delice, İ. (2017). Sözcük türleri. İstanbul: Asitan Kitap.

Dilidüzgün, Ş., Çetinkaya Edizer, Z., Ak Başoğul, D. ve Karagöz, M. (2019). Türkçe öğretiminde metin türüne uygun okuma eğitimi. Mersin Üniversitesi Ĕgitim Fakültesi Dergisi, 15(1), 165-185. doi: 10.17860/mersinefd.472247

Dornisch, M., Sperling, R. A., \& Zeruth, J. A. (2011). The effects of levels of elaboration on learners' strategic processing of text. Instructional Science, 39(1), 1-26.

Dunlosky, J., Rawson, K. A., Marsh, E. J., Nathan, M. J., \& Willingham, D. T. (2013). Improving students' learning with effective learning techniques: Promising direction from cognitive and educational psychology. Psychological Science and the Public Interest, 14, 4-58. doi: 10.1177/1529100612453266

Finn, B, Thomas, R., \& Rawson, K. A. (2018). Learning more from feedback: Elaborating feedback with examples enhances concept learning Learning and Instruction, 54, 10413. doi: 10.1016/j.learninstruc.2017.08.007

Fiorella, L., \& Mayer, R. E. (2016). Eight ways to promote generative learning. Educational Psychology Review, 28(4), 717-741. doi 10.1007/s10648-015-9348-9 
Foster, N. L., Rawson, K. A., \& Dunlosky, J. (2018). Self-regulated learning of principle-based concepts: Do students prefer worked examples, faded examples, or problem solving? Learning and Instruction, 55, 124-138. doi: 10.1016/j.learninstruc.2017.10.002

Gagne, R. M., Wager, W. W., Golas, K. C., \& Keller, J. M. (2005). Principles of instructional design (5th ed.). Wadsworth: Thomson Learning.

Griffin, M. M. (1993). Do student-generated rational sets of examples facilitate concept acquisition? The Journal of Experimental Education, 61(2), 104-115.

Hacıoğlu, Y. (2011). Bilimsel tartışma destekli örnek olayların 8.sınıf öğrencilerinin kavram ögrenmelerine ve okuduğunu anlama becerilerine etkisinin incelenmesi: Genetik (Yüksek lisans tezi). https://tez.yok.gov.tr/UlusalTezMerkezi/'nden erişilmiştir (Tez No. 298619).

Hamilton, J. R. (2004). Material appropriate processing and elaboration: The impact of balanced and complementary types of processing on learning concepts from text. British Journal of Educational Psychology, 74, 221-237.

Hannon, B. (2012). Differential-associative processing or example elaboration: Which strategy is best for learning the definitions of related and unrelated concepts. Learning and Instruction, 22(5), 299-310.

Hannon, B., Lozano, G., Farias, S., Hernandez, S. P., \& Fuhrman, R. (2010). Differentialassociative processing: A new strategy for learning highly-similar concepts. British Psychological Society Journals Virtual, 24(9), 1222-1244.

İncikabı, L. ve Kılıç, Ç. (2013). İlköğretim öğrencilerinin geometrik cisimlerle ilgili kavram bilgilerinin analizi. Kuramsal Ĕgitimbilim Dergisi, 6(3), 343-358.

Kalaycı, Ş. (2006). SPSS uygulamalı çok değişkenli istatistik teknikleri. Ankara: Asil Yayınları.

Karataş Coşkun, M. (2011). Kavram ögretimi. Adana: Karahan Kitabevi.

Kırılmazkaya, G. (2014). Web tabanlı araştırma-sorgulamaya dayall fen ögretiminin ögretmen adaylarının kavram ögrenmeleri ve bilimsel süreç becerilerinin geliştirilmesi üzerine etkisi (Yayınlanmamış doktora tezi). Marmara Üniversitesi, İstanbul.

Klausmeier, H. J. (1990). Conceptualizing. In B. F. Jones, \& L. Idol (Eds.), Dimensions of thinking and cognitive instruction (pp. 93-138). Hillsdale, NJ: Lawrence Erlbaum Associates.

Koçmar, Y. (2017). Ortaokul öğrencilerinin Türkçe dersinde kavram oluşturma süreçleri (Doktora tezi). https://tez.yok.gov.tr/UlusalTezMerkezi/'nden erişilmiştir (Tez No. 494198).

Korkmaz, Z. (2009). Türkiye Türkçesi grameri. Ankara: Türk Dil Kurumu Yayınları.

Kurt, E. (2018). Altıncı sınıf Türkçe dersi kavram öğretiminde animasyon ve hikaye kullaniminin başarıya etkisi (Doktora tezi). https://tez.yok.gov.tr/UlusalTez Merkezi/'nden erişilmiştir (Tez No. 511085).

Lewalter, D. (2003). Cognitive strategies for learning from static and dynamic visuals. Learning and Instruction, 13(2), 177-189.

Martorella, P. H. (1986). Teaching concepts. In J. M. Cooper (Ed.), Classroom teaching skills, (pp. 182-223). Lexington: D.C.Heath and Company.

Mayer, R. E. (1980). Elaboration techniques that increase the meaningfulness of technical text: An experimental test of the learning strategy hypothesis. Journal of Educational Psychology, 72(6), 770-784.

Merrill, M. D., Tennyson, R. D., \& Posey, L. O. (1992). Teaching concepts: An instructional design guide (2nd ed.). Englewood Cliffs. NJ: Educational Technology Publications.

Milli Eğitim Bakanlığ1 [MEB]. (2014). Ilköğretim yedinci sınıf Türkçe kitabı. Ankara: Ada Matbaacilik.

Milli Eğitim Bakanlığı [MEB]. (2018). Türkçe dersi (İlkokul ve ortaokul 1, 2, 3, 4, 5, 6, 7 ve 8. sinıflar için) ögretim programı. http://web.deu.edu.tr/ilyas/ftp/turkce_2018.pdf adresinden erişilmiştir. 
Özcan, Z. Ç., Kılıç, Ç. ve Obalar, S. (2018). Öğrencilerin matematikteki hatalarını belirleme ve gidermede açıklayıcı ipuçlarıyla desteklenmiş çözümlü örnekler. Mehmet Akif Ersoy Üniversitesi Eğitim Fakültesi Dergisi, 45, 1-22. doi:10.21764/maeuefd.322223

Özderi, T. (2010). İlköğretim 8. sınıf öğrencilerinin yazılı anlatım becerilerinde zarf kullanımı üzerine bir araştırma (Yüksek lisans tezi). https://tez.yok.gov.tr/UlusalTez Merkezi/'nden erişilmiştir (Tez No. 265285).

Özel, S. (2018). Türkiye Türkçesi temel dil bilgisi. Ankara: Dil Derneği Yayınevi.

Park, O. C. (1984). Example comparison strategy versus attribute identification strategy in concept learning. American Educational Research Journal, 21(1), 145-162.

Pesonen, J. P. (2002). Concepts and object-oriented knowledge representation (Unpublished master's thesis). University of Helsinki, Finland.

Pınar, A. ve Akdağ, H. (2012). Sosyal bilgiler öğretmen adaylarının iklim, rüzgâr, sıcaklık, yă̆ış, erozyon, ekoloji ve harita kavramlarını anlama düzeyi. İlköğretim Online, 11(2), $530-542$.

Polatcan, F. (2013). 6. Sinıflarda kavram haritalarlyla dilbilgisi öğretiminin başarıya etkisi (Yüksek lisans tezi). https://tez.yok.gov.tr/UlusalTezMerkezi/'nden erişilmiştir (Tez No. 331720).

Rawson, K. A., \& Dunlosky, J. (2016). How effective is example generation for learning declarative concepts? Educational Psychology Review, 28(3), 649-672.

Rawson, K. A., Thomas, R. C., \& Jacoby, L. L. (2015). The power of examples: Illustrative examples enhance conceptual learning of declarative concepts. Educational Psychology Review, 27(3), 483-504.

Roelle, J., Hiller, S., Berthold, K., \& Rumann, S. (2017). Example-based learning: The benefits of prompting organization before providing examples. Learning and Instruction, 49,112.

Sağlam Kaya, Y. (2019). Matematik öğretmenlerinin öğrenen tarafindan üretilen örnekleri sınıfta kullanma sıklıklarının ve gerekçelerinin incelenmesi. Eğitim ve Bilim, 44(199), 21-47.

Sayal1, S. (2009). Türkiye Türkçesinde zarflar ve zarflaştırma (Yüksek lisans tezi). https://tez.yok.gov.tr/UlusalTezMerkezi/'nden erişilmiştir (Tez No. 253347).

Sayın, K. Ö. (2014). Illkögretim 5.sınıf Türkçe derslerinde çoklu zeka kuramı temelinde kavram ögretimi (Yüksek lisans tezi). https://tez.yok.gov.tr/UlusalTezMerkezi/'nden erişilmiştir (Tez No. 370193).

Schunk, D. H. (2014). Öğrenme teorileri eğitimsel bir bakışla (Çev. Ed. M. Şahin). Ankara: Nobel Akademi Yayınları.

Süğümlü, Ü. (2009). Dil bilgisi öğretiminde senaryo tabanlı ögrenme yaklaşımının etkililiği: Kelime türleri örneği (Yüksek lisans tezi). https://tez.yok.gov.tr/UlusalTez Merkezi/'nden erişilmiştir (Tez No. 253285).

Şengül, M. ve Yalçın, S. K. (2004). Okuma ve yazma becerilerinin geliştirilmesine yönelik olarak hazırlanan bir model önerisi. Milli Eğitim Dergisi, 164, 17-21.

Talaslıoğlu, S. S. (2016). Ortaokul 7. sinıf öğrencilerinin grafik okuryazarlı̆̆ etkinlikleri ile karar verme becerileri ve kavram ögrenmeleri arasındaki ilişkinin incelenmesi (Yüksek lisans tezi). https://tez.yok.gov.tr/UlusalTezMerkezi/'nden erişilmiştir (Tez No. 445637).

Tan, E. (2008). İlköğretim 7. sinıf dil bilgisi ögretiminde zarflar konusuyla ilgili yapılandırmacı yaklaşıma göre hazırlanmış çalışma yapraklarının öğrenci başarısına etkisi (Yüksek lisans tezi). https://tez.yok.gov.tr/UlusalTezMerkezi/'nden erişilmiştir (Tez No. 254889).

Temizyürek, F. ve Türktan, R. (2015). Yapılandırılmış grid test tekniğinin Türkçe eğitiminde kavram öğretimine katkısı. Mersin Üniversitesi Eğitim Fakültesi Dergisi, 11(2), 271287. doi: 10.17860/efd.94443

Tennyson, R. D., \& Cocchiarella, M. J. (1986). An empirically based instructional design theory for teaching concepts. American Educational Research Association, 56(1), 40-71. 
Tennyson, R. D., \& Park, O. C. (1980). The teaching of concepts: A review of instructional design research literature. Review of Educational Research, 50(1), 55-70.

Uc, F. B. (2019). Yazma destekli argümantasyon uygulamalarının 7.sını ögrrencilerinin yazma öz yeterliklerine, yaratıc yazmalarına ve kavram öğrenmelerine etkisinin incelenmesi (Yüksek lisans tezi). https://tez.yok.gov.tr/UlusalTezMerkezi/'nden erişilmiştir (Tez No. 584674).

Usta, R. (2010). Türkiye Türkçesinde zarflar (Yüksek lisans tezi). https://tez.yok.gov.tr/ UlusalTez Merkezi/'nden erişilmiştir (Tez No. 273118).

Uysal, F. G. (2016). 6. ve 7. sinıf ögrencilerinde kesirler konusunda metafor yardımıyla kavram oluşturma. (Yüksek lisans tezi). https://tez.yok.gov.tr/UlusalTezMerkezi/'nden erişilmiştir (Tez No. 456564).

Watson, A., \& Shipman, S. (2008). Using learner generated examples to introduce new concepts. Educational Studies in Mathematics, 69(2), 97-109.

Yamaç, A. (2010). Dedemin gizli defteri. İstanbul: Bu Yayınevi.

Yaman, H. (2006). İlkögretim ikinci kademe Türkçe dilbilgisi derslerinde kavram haritası tekniğinin ögrenci başarısina ve hatırlamaya etkisi (Doktora tezi). https://tez.yok.gov.tr/UlusalTezMerkezi/'nden erişilmiştir (Tez No. 191707).

Yenilmez, K. ve Demirhan, H. (2013). Altıncı sınıf öğrencilerinin bazı temel matematik kavramları anlama düzeyleri. Dicle Üniversitesi Ziya Gökalp Eğitim Fakültesi Dergisi, 20, 275-292.

Yıldız, K. (2013). Fen ve teknoloji öğretiminde bellek destekleyici stratejilerin öğrencilerin başarılarına ve kavram öğrenmelerine etkisi (Yüksek lisans tezi). https://tez.yok.gov.tr/UlusalTezMerkezi/'nden erişilmiştir (Tez No.350017 ).

Zamary, A., \& Rawson, K. A. (2018a). Which technique is most effective for learning declarative concepts-provided examples, generated examples or both? Educational and Psychology Review, 30(1), 275-301. doi: 10.1007/s10648-016-9396-9

Zamary, A., \& Rawson, K. A. (2018b). Are provided examples or faded examples more effective for declarative concept learning? Educational and Psychology Review, 30(3), 1167-1197. doi: 10.1007/s10648-018-9433-y

Zaslavsky, O. (2014). Thinking with and through examples. In S. Oesterle, P. Liljedahl, C. Nicol, \& D. Allan (Eds.), Proceedings of the Joint Meeting of the 38th Conference of the International Group and the 36th Conference of the North American Group for the Psychology of Mathematics Education (Vol. 1, pp. 21-34). Vancouver: PME.

\section{Introduction}

\section{Extended Abstract}

Examples play an important role in the formation of conceptual understanding. Examples and non-examples affect concept learning positively as they make the definition and features of the concept more concrete and clear. However, which way is most effective in teaching concepts? The answer to the question may not be valid in all situations. Hannon (2012) stated that "there are no simple answers because no one strategy is the panacea for learning problems". However, it can be tested whether there is a better way. Example elaboration is one of the strategies studied in order to obtain a more effective and efficient result in concept learning. (Charney \& Reder, 1986; Hamilton, 2004; Hannon, 2012; Hannon, Lozano, Farias, Hernandez \& Fuhrman, 2010; Mayer, 1980; Park, 1984).

Elaboration is any kind of enhancement that clarifies the link between the new information to be learned and the previous information (Charney \& Reder, 1986; Hamilton, 2004). In concept teaching, elaboration is mostly seen as "example elaboration". Example elaboration in concept teaching can take different forms as follows; the student's comparing the differences between the definitions of the concept, showing the critical attributes on the presented examples, explaining why the example is an example using the solved example in terms of the definition 
and the attributes; comparing examples and non-examples, creating/giving an example of the concept using the student's cognitive schema (Hannon, 2012; Hannon et al., 2010).

Different teaching strategies can be used in order for students to correctly understand the concepts that are difficult to learn in grammar. The studies examining the effect of example elaboration strategy in concept teaching in Turkey could not be found. In addition, it has been determined that the concept of adjectives is mostly studied in Turkish lessons (Bayram, 2015; Child, 2012; Polatcan, 2013; Sög̈ümlü, 2009). It can be stated that there are fewer studies on teaching the concept of adverbs (Cevher, 2019; Tan, 2008). Therefore, it can be stated that this study may be useful for teaching basic concepts related to grammar. The aim of this study is to determine the effect of example elaboration strategy on concept learning success, retention and transfer. According to this, answers to the following questions were sought:

1. When the experimental and control group students' concept learning pretest and reading comprehension pretest total scores are checked, does the concept learning posttest adjusted scores show a significant difference in favor of the experimental group using the example elaboration strategy?

2. When the concept learning posttest total achievement scores of the experiment and control group students are checked,

2a. Does the retention test adjusted scores show a significant difference in favor of the experimental group using the example elaboration strategy?

2b. Does the transfer test adjusted scores differ significantly in favor of the experimental group using the example elaboration strategy?

\section{Method}

In this study, the experimental design with pre-test post-test control group was used to teach the concept of adverb. The effects of the example elaboration strategy on concept learning success, retention and transfer were investigated, and participants were assigned to the experimental conditions through neutral appointment. While the participants are assigned neutral to experimental conditions in the actual experiment patterns, there is no neutral assignment in the other two designs (Büyüköztürk, 2001).

This research was carried out at a full-time public school in Adana province in the 2018-2019 academic year, where the first author of the research has been working as a Turkish teacher for seven years. The majority of the students at the school are the children of immigrants, lowincome families with a large number of siblings. 35 students were assigned to the experimental group and 34 students to the control group in a neutral way. However, three students in both groups were excluded from the study group, who did not participate in the entire experimental process for various reasons, such as not taking the pre-test or post-test concept learning test, not taking the retention and transfer tests and not filling these tests in accordance with the rules specified in the directive. The study group consisted of students who took part in all stages of the experimental process, took all the tests and filled them in accordance with the instructions. The study included 30 students in the experimental group and 30 students in the control group. In the research, whether the students in the experimental and control groups were equivalent in terms of Turkish lesson academic achievement grades, gender, reading comprehension, adverb concept learning test were tested before the experimental process. Turkish lesson academic achievement grades were obtained by repeating the average of the year-end academic achievement of the fifth and sixth grade Turkish lessons.

In this study, the data were collected using reading comprehension test (RCT), concept learning test (CLT) and transfer test. In the experimental process, work booklets, worksheets and powerpoint presentation prepared by the researchers were used. In this study, whether there was a significant difference between the total scores of the experimental and control groups and 
between RCT and CLT pre-test was analyzed by independent groups $t$ test. In order to determine whether there was a significant difference among the post-test, transfer tests and retention test total success scores of the experimental and control groups, covariance analysis was performed. In the research, the effect size (effect size-square, $\eta 2$ ) value was also calculated in order to determine how much of the total variance in the dependent variables can be explained by the independent variable.

\section{Result and Discussion}

When the total scores of CLT and RCT pre-tests applied to the experimental and control groups were checked in the study, the main effect of the grouping was found to be significant in favor of the experimental group in terms of the post-test total adjusted means $(F(1-56)=59.363, \mathrm{p}<$ $.05 ; \eta 2=0.51$ ). According to the finding obtained, it can be stated that the example elaboration strategy applied for the teaching of the concept of adverb in the experimental group was effective for the post-test, and the students in this group acquired information about the concept of the adverb and the types of the adverb. In the experimental process in this study, it was not only satisfied with the presentation of examples and non-examples, but also the students were provided to make sense of the information presented through elaborated activities that required establishing the relationship between an example and attributes. With elaborating, the students added a unique way to his cognitive schema by recording information in memory without departing from its true meaning (Hannon, 2012). Thus, it can be stated that it strengthens the cognitive structure. This result obtained in this study regarding the effect of the example elaboration overlapped with previous studies (Bolkan \& Goodboy, 2019; Rawson et al., 2015; Roelle et al., 2017).

When the post-test total achievement scores of the experimental and control group students were checked, it was determined that the main effect of the grouping was not significant in terms of the retention test adjusted mean of the experimental group students $(\overline{\mathrm{X}}=16.08)$ and the retention test adjusted mean of the control group students $(\bar{X}=15.95)(F(1-57)=.043, \mathrm{p}>$ $.05, \eta 2=0.00)$. This result shows that after the post-tests, students in the control groups may have had a learning, which may have affected the retention test scores, and the students in the control group may have increased their knowledge of the adverb concept with their own efforts regarding the concept of adverb. However, it can be stated that the number of examples produced by students as a result of the example elaboration strategy used in the experimental group may have been insufficient for retention of learning to take place. In addition, the students in the experimental group may not have repeated what they learned until the application of the retention test. There are also studies in the literature that show different results about the effect of the example elaboration strategy (Rawson \& Dunlosky, 2016; Zamary \& Rawson, 2018a; Zamary \& Rawson, 2018b; Dornisch et al., 2011).

As a result, when the post-test total achievement scores of the experimental and control group students were checked, the transfer test adjusted mean of the experimental group students ( $\overline{\mathrm{X}}=$ 17.09) and the adjusted mean of the control group $(\bar{X}=14.08)$ did not make a significant difference in the group effect $(F(1-57)=3.042, \mathrm{p}>.05, \eta 2=0.05)$. In the transfer test, although there was no significant difference was observed between the experimental and control groups, it was observed that the students in the experimental group made full and accurate explanations that included more details than the students in the control group. Consequently, when the results of this study are evaluated as a whole, considering the total scores of the students in the experimental and control groups for the concept learning and reading comprehension skill pretests, there was a significant difference between the adjusted means of the concept learning post-test in favor of the experimental group. When the post-test total achievement scores were controlled, no significant difference was found between the adjusted means of the retention test and transfer test in favor of the experimental group. 
Nergiz ve Akbulut Taş

\section{EK 1: Transfer Testi Puanlama Anahtarı}

\begin{tabular}{lc}
\hline Ölçütler & Puan \\
\hline Zarf görevindeki sözcük ya da sözcük grubunu ve türünü doğru olarak belirleme & 1 \\
\hline Belirlenen zarf türünün gerekçesini doğru ve tam bir şekilde açıklama & 1 \\
\hline $\begin{array}{l}\text { Zarf görevindeki sözcük ya da sözcük grubunu eksik belirleme ancak türünü } \\
\text { doğru belirleme }\end{array}$ & 0,5 \\
\hline $\begin{array}{l}\text { Zarf görevindeki sözcük ya da sözcük grubu tam ve doğru belirleme ancak türünü } \\
\text { yanlıs belirleme }\end{array}$ & 0 \\
\hline Belirlenen zarf türünün gerekçesiyle ilgili eksik açıklama & 0,5 \\
\hline
\end{tabular}

